\title{
BREASTFEEDING: MAKING THE DIFFERENCE IN THE DEVELOPMENT, HEALTH AND NUTRITION OF TERM AND PRETERM NEWBORNS
}

\author{
Maria Beatriz Reinert do Nascimento and Hugo Issler
}

NASCIMENTO MBR do et al. - Breastfeeding: making the difference in the development, health and nutrition of term and preterm newborns. Rev. Hosp. Clín. Fac. Med. S. Paulo 58(1):49-60, 2003.

Breastfeeding is the natural and safe way of feeding small infants, providing nutritional, immunological, psychological and economic recognized and unquestionable advantages. These qualities are especially important in premature infants, because of their vulnerability. Despite highly desirable, there is, in general, little success in breastfeeding preterm infants, especially in special care neonatal units. There are evidences that a high supportive hospital environment, with an interdisciplinary team, makes possible to these infants to be breastfed. In this article, the authors present an up-to-date review about the components of human milk and its unique characteristics, as well as describes aspects that make the breast milk particularly suitable for feeding the premature newborn.

DESCRIPTORS: Infant feeding. Breastfeeding. Human milk. Newborn. Premature infant.

\section{INTRODUCTION}

Maternal breastfeeding is the most natural and safe way to feed a small child. Breastfeeding provides a unique combination of proteins, lipids, carbohydrates, minerals, vitamins, enzymes and living cells, as well as known and unquestionable nutritional, immunological, psychological and economic benefits $^{1-6}$.

The nutritional composition of breast milk, which possesses the exact proportion of nutrients for good development of the human brain, differs from the milk of other mammals, such as rabbit milk which contains large amounts of protein for rapid growth of the species, or from whale milk which is rich in fat in order to guarantee survival in cold water ${ }^{7}$. Human milk is a complex species-specific biological fluid, adapted throughout human existence to perfectly satisfy the nutri- tional and immunological needs of the child $^{1,3,8}$.

Lactation progresses through three well-identified periods, i.e., the stages of colostrum, transition milk and mature milk ${ }^{4}$. Colostrum is a yellowish fluid of high density and small volume that fills the alveolar cells during the last trimester of gestation ${ }^{1}$. Its high content of proteins and minerals, in addition to low concentrations of fat and lactose, reflects the needs of the newborn during the first week of life ${ }^{8}$. Colostrum provides $67 \mathrm{kcal} / \mathrm{dl}$, is rich in immunoglobulins, lactoferrin and leukocytes, and facilitates the growth of Lactobacillus bifidus in the gastrointestinal tract and the elimination of meconium ${ }^{9,10}$.

From the Department of Pediatrics, Hospital das Clínicas, Faculty of Medicine, University of São Paulo.

Received for publication on April 23, 2002.
The transitional phase lasts from the seventh to the tenth day, up to two weeks post partum, during which the composition of colostrum changes, with a decrease in the concentration of immunoglobulins and proteins and an increase in lactose and fat levels and in energy content, until reaching the characteristics of mature milk ${ }^{10}$.

Mature human milk is a homogenous mixture consisting of three fractions: emulsion (fat droplets), suspension (casein micelles) and solution (water soluble components $)^{4,11}$. Different energy contents have been described to mature milk in the literature, ranging from $65.7 \mathrm{kcal} / \mathrm{dl}^{12}, 71 \mathrm{kcal} / \mathrm{dl}^{13}$ to 75 $\mathrm{kcal} / \mathrm{dl}^{10}$. Variations in the nutritional components of human milk exist, which depend on the stage of lactation, the time of day, period of feeding, maternal nutrition and age, and gestational age of the infant, as well as individual aspects of each lactating mother ${ }^{5,8,10}$. 


\section{NUTRITIONAL COMPOSITION OF HUMAN MILK}

With respect to the biochemical composition of human milk, maternal milk contains $88 \%$ of water and its osmolarity is similar to that of plasma ${ }^{2}$. Therefore, exclusive breastfeeding on demand, without water supplementation, keeps the nursing infant perfectly hydrated ${ }^{1,11}$.

The total protein content of human milk is the lowest among all mammals due to the relatively slow growth of the child ${ }^{14}$. The real amount is about 0.8 to $0.9 \mathrm{~g} / \mathrm{dl}$, including a high fraction of non-protein nitrogen corresponding to 20 to $25 \%{ }^{1,3}$. However, many of the properties beneficial to the nursing infant can be attributed to the protein compartment, such as defense factors, digestive enzymes, hormones and growth factors ${ }^{4}$.

Milk proteins include casein and lactalbumins, or serum proteins ${ }^{10}$, and are not completely available for nutritional use by the nursing infant, since those with a defense function against infections appear intact in the feces and are not absorbed ${ }^{4}$. Casein forms stable conglomerates with calcium and phosphorus, thus favoring the transport of these minerals ${ }^{11,13}$. The main serum proteins include a-lactalbumin, important for the synthesis of lactose, and protective factors such as lactoferrin, lysozyme and immunoglobulins. $\beta$ Lactoglobulin, which is highly allergenic, is predominantly found in cow's milk, and is only detected in small amounts in human milk where it probably originates from cow's milk ingested by the breastfeeding mother ${ }^{4,14}$. The serum protein/casein ratio in human milk reported in different studies ranges from $80 / 20$ to $60 /$ 40 , a fact that results in the formation of a smoother gastric curd, reducing the time of gastric emptying and facilitating digestion ${ }^{1,8,10}$.

The amino acid composition of human milk is perfectly adequate, with a reduced amount of phenylalanine and tyrosine. The newborn shows a reduced capacity of metabolizing these aromatic elements which, at high plasma levels, can cause lethargy ${ }^{13}$. Taurine, important for the development of the retina and for the stability of cell membranes, is found in human but not in cow's milk ${ }^{14}$. The ratio of the sulfur-containing amino acids methionine/cystine in human milk is close to one, a ratio seven times lower than that found in cow's milk ${ }^{10}$. The enzyme cystathionase, which is responsible for the transformation of methionine to cystine, is absent in the brain and liver of premature newborns, and thus cystine becomes essential for these children ${ }^{1}$. Human milk also contains carnitine, a protein of high bioavailability, which is vital during immediate post-natal life for the degradation of long-chain fatty acids, since newborns show a reduced capacity to synthesize carnitine $e^{8,14,15}$. The decrease in protein content during the course of lactation leads to the fact that human milk, without the use of additional components, is not completely adequate for the feeding of premature newborns ${ }^{16}$.

Fat is the most variable component of maternal milk, corresponding to 3$4 \mathrm{~g} / \mathrm{dl}^{13}$, and represents the main energy source for the newborn, providing 35 to $50 \%$ of its daily needs ${ }^{1}$. Almost all lipids in human milk are present in the form of droplets, which permit stabilization of the emulsion and increases the bioavailability of liposoluble components ${ }^{1}$. Lipid components include triglycerides, phospholipids and cholesterol, as well as free fatty acids, and are derived from circulating fat originating from the diet and from maternal body reserves, or are synthesized from glucose in the breast itself ${ }^{5}$.

Human milk shows a high concentration of cholesterol, with its plasma concentration being higher in breastfeeding infants than in those fed artificial milks. There is evidence showing the beneficial effect of a higher cholesterol concentration during this phase of life based on its better bioavailability to the developing brain and for maintaining low and appropriate blood levels of cholesterol during adult life $\mathrm{e}^{1,10,14}$.

Digestion of triglycerides in the neonate is facilitated by a combination of enzymes, such as lingual lipase which initiates hydrolysis in the digestive tract, gastric lipase, pancreatic lipase and, especially, bile-stimulated lipase provided by the human milk fat droplets themselves and activated by bile salts in the duodenum ${ }^{3,11}$.

Human milk represents the best source of essential fatty acids. A great difference between human and artificial milk concerns the concentration of long-chain polyunsaturated fatty acids, which are essential for the normal development of nursing infants, with emphasis on docosahexaenoic acid which is important for the development of the brain and retina, and arachidonic acid as a precursor of prostaglandins and leukotrienes ${ }^{17}$. The reserves of these fat elements are limited at birth, especially in premature newborns, and rapidly decrease when lacking in the diet ${ }^{18}$. Several clinical studies have demonstrated that enrichment of industrialized infant milk with long-chain polyunsaturated fatty acids, simulating the composition of human milk, improves visual and cognitive functions in term and preterm newborns ${ }^{19}$. However, further studies are needed to determine the long-term beneficial effects of this supplementation and its side effects ${ }^{17,19}$.

The main carbohydrate of human milk is lactose, whose concentration is about $7 \mathrm{~g} / \mathrm{dl}$ and which is metabolized into galactose, the primary source of the white matter of the growing brain $^{1,8}$. Lactose facilitates the absorp- 
tion of calcium ${ }^{3,14}$ and supports the presence of a fecal flora protective against bacteria and of feces of adequate consistency ${ }^{20}$. Other sugars, such as glycolipids, glycoproteins and oligosaccharides, exist which play an important role in the defense against infections ${ }^{3,4}$.

The concentration of minerals in maternal milk is about one-third lower than in cow's milk ${ }^{13}$. This fact, together with the reduced protein content, leads to a lower solute load which is adequate for the newborn's immature kidney ${ }^{8}$. The total mineral content of human milk is generally constant and includes minerals such as sodium, potassium, chloride, calcium, magnesium and phosphorus, and the trace elements iron, fluor, zinc, copper, manganese, selenium, and iodide ${ }^{5}$.

Several studies have demonstrated a high bioavailability of minerals and their relationship with other nutrients present in human milk, which facilitates their absorption, metabolism and excretion $^{3}$. Although present in small amounts in human milk, calcium is well absorbed and its concentration is sufficient in term newborns, with a calcium/phosphorus ratio of $2: 1^{8}$. However, the calcium and phosphorus concentrations are too low to satisfy the requirements of bone mineralization in preterm infants ${ }^{20}$.

The sodium content of human milk declines during the course of lactation. This reduced concentration, together with the high potassium content, seems to be beneficial to the nursing infant; however, it does not satisfy the needs of premature newborns who require large amounts of this mineral ${ }^{16}$. The high bioavailability of zinc in human milk compensates for its low concentration, with zinc deficiency being rare, thus preventing enteropathic acrodermatitis in breastfeeding infants ${ }^{1,8}$.

Iron deficiency is a rare disorder in breastfeeding infants since, even in the case of a low iron content, its absorp- tion from human milk is five times higher than absorption from cow's milk and is facilitated by the presence of lactose and vitamin $\mathrm{C}$, as well as by low levels of protein and phosphorus in maternal milk ${ }^{3,8}$.

All water soluble vitamins are found in breast milk, and the concentration of vitamin $\mathrm{C}$ is eight to ten times higher than in the mother's plasma. Vitamin $B_{12}$ levels are frequently low in the milk of mothers consuming vegetarian diets, a fact that might lead to deficiency of this compound in the nursing infant ${ }^{5}$. Of the liposoluble vitamins, vitamin $\mathrm{A}$ and $\mathrm{E}$ contents are adequate in human milk. However, vitamin K supplementation is required for all newborns since its endogenous production by enteric bacteria only starts some days after birth. The low vitamin D concentration in human milk requires the use of exogenous vitamin supplements in the case of nursing infants who are not regularly exposed to the $\operatorname{sun}^{3,18}$.

\section{IMMUNOLOGICAL COMPOSITION OF HUMAN MILK}

One of the most valuable aspects of human milk is the presence of defense elements which, together with the perfect composition and purity of this milk ${ }^{14}$, guarantee a protective effect in terms of child morbidity and mortality ${ }^{6,21-24}$.

The protective components of human milk conferring active and passive protection on the newborn and nursing infant can be divided into specific and nonspecific cellular and humoral factors ${ }^{10}$. Cellular defense elements include live leukocytes, which are present in high numbers at the beginning of lactation ${ }^{9}$ and are known to exert activity in the gastrointestinal tract of the nursing infant, inducing a local and systemic immune response.
The predominant immunocompetent cells in human milk are macrophages (40-50\%) and polymorphonuclear neutrophils $(40-50 \%)$, which have phagocytic capacity and exert bactericidal and fungicidal actions ${ }^{25}$. In addition, macrophages synthesize the $\mathrm{C} 3$ and $\mathrm{C} 4$ complement components, lysozyme and lactoferrin, and are a vehicle for the transport and storage of immunoglobulins ${ }^{10}$. Lymphocytes represent 5 to $10 \%$ of white cells of milk, and are mainly formed by $\mathrm{T}$ lymphocytes which exert a cytotoxic action on microorganisms and stimulate the immunological system of the nursing infant, while B lymphocytes are responsible for the production of specific antibodies against numerous pathogens ${ }^{8}$.

When a pathogen in the respiratory or digestive tract of the maternal organism is captured by a macrophage, the antigenic information is passed on to $\mathrm{T}$ lymphocytes and then to $\mathrm{B}$ lymphocytes, which, upon transformation into plasma cells, release specific antibodies directly into the breast. The enterobronchomammary system assures that any pathogen threatening the mother stimulates the production of specific antibodies which are found in maternal milk ${ }^{1}$.

The specific soluble factors are represented by immunoglobulins (Ig). The main immunoglobulin is secretory $\operatorname{IgA}$, which corresponds to $10 \%$ of milk protein and prevents the adhesion of microorganisms to the intestinal surface, in addition to acting against diverse infectious agents such as rotavirus, respiratory syncytial virus, Escherichia coli, Vibrio cholerae, Shigella, Salmonella, Clostridium difficile, Giardia lamblia and Campylobacter. Secretory $\operatorname{IgA}$ includes dimeric IgA bound to polymeric immunoglobulin receptors ( $\mathrm{J}$ chain) and conjugated to a glycoprotein produced in epithelial cells, which represents the secretory component ${ }^{25}$. 
The milk of mothers of low birthweight newborns contains larger amounts of IgA than the milk of mothers of term infants, conferring greater protection during a period when the child is more susceptible to infection $^{26}$.

With respect to the other antibodies of the different immunoglobulin classes, IgD participates in the immune response in the mammary gland. IgE, together with antigens in the intestinal lumen, releases chemical mediators that increase vascular permeability, facilitating the liberation of IgG to perform its opsonizing activity on bacteria and viruses. $\operatorname{IgG}$ also mediates the activation of the complement system, while IgM is important for the initial protection of neonates exposed to maternal infections ${ }^{25}$.

Many nonspecific protective factors are found in human milk. Lactoferrin is a protein that acts as a bacteriostatic agent by depriving microorganisms of iron, in addition to exerting bactericidal, antiviral, anti-inflammatory and immunomodulatory activities ${ }^{25,27}$. Lysozyme is a protein component found in large amounts in human milk, which mediates bacterial lysis and can exert an immunomodulatory effect by releasing elements from the bacterial cell wall $^{25,27}$.

The components of the complement system are found in colostrum and mature milk, but in smaller amounts than those observed in maternal serum or in the nursing infant, and protect against respiratory and enteric infections. Vitamin $\mathrm{B}_{12}$-binding protein prevents the incorporation of this vitamin by $E$. coli and bacterioids, thus inhibiting their growth $^{10}$.

Some fat elements of human milk also show antimicrobial functions. Among the components of the cell membrane of fat droplets, glycoproteins such as mucins prevent the binding of bacteria and viruses to the intestinal mucosa ${ }^{27,28}$. In addition, the detergent action of free fatty acids and monoglycerides released by the hydrolysis of triglycerides mediates the lysis of bacteria, viruses and protozoans ${ }^{27}$.

Oligosaccharides promote the development of the bifid flora which, through a decrease in $\mathrm{pH}$, impairs the multiplication of enterobacteria such as Shigella, Salmonella and E. coli, and inhibits the adhesion of bacteria such as Pneumococcus to mucosal surfaces, thus playing an important role in the prevention of infectious diseases in newborns ${ }^{4}$.

Evidence indicates the existence of numerous other protective factors in addition to those described earlier, for example, gangliosides, resistance factor, interferon, fibronectin, glycosaminoglycans, and stimulated bile lipase $^{10,27,28}$. In addition to its anti-infectious function, new studies have demonstrated that human milk can modulate the immune response in the nursing infant through immunomodulatory and anti-inflammatory substances that alter the host's reaction to injury ${ }^{30}$.

The immunomodulatory factors present in maternal milk include prolactin, lactoferrin, nucleotides and cytokines which, in addition to their other biological and antimicrobial functions, are able to actively regulate the synthesis and maturation of the immune system of the neonate. This activity stimulates lymphocyte proliferation and the production of immunoglobulins, and increases cell activity. A direct antiinflammatory action of maternal milk has not yet been demonstrated in vivo, but epidemiological studies have suggested that the breastfeeding infant is protected against infection, without the observation of evident lesion of the intestinal or respiratory mucosa due to an inflammatory response. This is the result of a well-established anti-inflammatory system in human milk and has been discovered only recently. The antiinflammatory factors include anti- proteases, interleukins, prostaglandins, acetylhydrolase of platelet activating factor, secretory IgA, and antioxidants such as vitamins and peroxidases. Hormones and growth factors also play an important role by promoting gastrointestinal maturation and by contributing to the development of the neonate's own defenses ${ }^{31}$.

\section{THE MAIN ADVANTAGES OF BREASTFEEDING}

Based on the anti-infectious, antiinflammatory and immunomodulatory properties of human milk described earlier, breastfeeding offers protection against diverse pathologies ${ }^{8,32}$, with a consequent reduction in the incidence of hospital admissions ${ }^{21}$.

Maternal milk confers protection against gastrointestinal and respiratory infections ${ }^{23,24}$. Children who have not been breastfed show a 17-fold higher probability of being hospitalized due to pneumonia than those who exclusively received human milk. This possibility is even higher in nursing infants aged less than three months ${ }^{33}$.

In developing countries, the main causes of death in the pediatric age range are protein-calorie malnutrition and infectious diseases, especially gastroenterocolitis. Malnutrition is particularly observed in places where the weaning diet has a low nutritional value. In these countries, the effect of natural feeding on infant mortality is significant ${ }^{34-36}$. The risk of death due to diarrhea and acute respiratory infections increases 14.2- and 3.6-fold in weaned infants, respectively ${ }^{22}$. Breastfed infants show a greater protection against death due to infection and, at a lower age, a higher mortality risk when not breastfed. The probability of death due to infectious diseases during the first two months of life is six times higher in non-breastfed infants ${ }^{6}$. 
Breastfeeding has been also associated with a reduction in the incidence of acute otitis media ${ }^{37}$, urinary tract infection ${ }^{38}$, and meningitis caused by Haemophilus influenzae $e^{39}$.

Allergic diseases are also less common and less severe in breastfed infants $^{8}$. Artificial feeding has been associated with a higher incidence of asthma, diarrhea, vomiting and prolonged colds ${ }^{40}$. Around the third or fourth month of life, $62 \%$ of infants fed artificial milk present chronic nasal obstruction and diarrhea versus $13 \%$ of breastfed infants ${ }^{41}$. A longterm follow-up study has demonstrated that the prevalence of atopic manifestations, including eczema and food and respiratory allergies, is higher in the group of non-breastfed patients or patients breastfed for a short period of time ${ }^{42}$.

The action of human milk on the immune system of the nursing infant might explain the finding that allergic disorders ${ }^{8,42}$ and insulin-dependent diabetes $^{43}$ are less prevalent in breastfed children, and that weaning has been described as a risk factor for Crohn's disease $^{44}$, childhood lymphoma ${ }^{45}$, and even for breast cancer during adulthood $^{46}$. This effect should also be considered to explain the better response of antibody production after vaccine doses against poliomyelitis, tetanus and diphtheria in breastfeeding infants compared to those receiving artificial milk $^{47}$.

Breastfeeding also has a beneficial effect on the development of the oral cavity of the child, leading to adequate tooth alignment and rare cases of malocclusion, thus reducing the need to use an orthodontic apparatus and the risk of sleep apnea during adulthood $^{48}$. Breastfed infants show a lower incidence of caries $^{2}$, while infants receiving bottles containing milk or juice rich in carbohydrates at night show a higher risk of developing bottle caries $^{49}$.
A recent meta-analysis has suggested that breastfeeding is associated with a $50 \%$ lower risk of sudden infant death syndrome, although the etiology of this event is still not well established and the studies analyzed presented limitations ${ }^{50}$.

The long-term effects of breastfeeding include a reduced risk of obesity, since breastfeeding is associated with a lower rate of obese children (2.8 versus $4.5 \%$ of children who have never been breastfed). Thus, breastfeeding represents a preventive measure for reducing the incidence of cardiovascular diseases and other disorders resulting from overweight ${ }^{51}$.

Breastfeeding provides better conditions for the development of the mother-child bond. The psychological effects of breastfeeding on the mother and the child have been widely recognized, since preparing the newborn for breastfeeding establishes a proximity between them that is the optimal distance for the infant to visualize its mother's face ${ }^{52}$. This affective connection leads to reciprocal feeding from the psychological point of view ${ }^{53}$. The early contact between the mother and her child since birth and during lying in together can increase the incidence and duration of breastfeeding and reduce the occurrence of abuse, negligence and abandonment during child$\operatorname{hood}^{54}$.

At the time the newborn is breastfed, alterations occur in its cerebral activity, which are characterized by a significant increase in the amplitude of its electroencephalogram in the posterior cortical areas of both hemispheres which are related to mechanisms involved in hunger, satiety, regulation of affective satisfaction and sleep cycle modulation ${ }^{55}$.

Breastfeeding has been correlated with the child's cognitive prognosis. Breastfed infants show significantly better scores in developmental tests than those receiving artificial milk, with a greater benefit being observed for low birthweight infants and with a longer duration of breastfeeding ${ }^{56}$.

Maternal breastfeeding has a higher social impact in poor countries where the use of human milk as a nutritional source is crucial due to its economic value ${ }^{57}$. Breastfeeding leads to significant savings for the family since no money is spent on the acquisition of maternal milk substitutes or medication, and for society as a whole. Not breastfeeding increases the costs for the health system. For each one thousand non-breastfed infants, there is an additional number of 2033 pediatric visits, 212 days of hospitalization, and 606 medical prescriptions for the treatment of diarrhea, respiratory diseases and acute otitis, media compared to children exclusively breastfed for at least three months. This additional demand generates an extra cost of US\$331 to US\$475 for each child during the first year of life ${ }^{58}$.

The act of breastfeeding corresponds to a significant part of the reproductive life of a woman, generating new sensations and improving her selfesteem $^{59}$. In addition, the beneficial effects of breastfeeding on maternal health are numerous. In the breastfeeding puerpera, adequate involution of the uterus accompanied by a reduction in post-partum bleeding protects the maternal iron reserves, thus leading to lower rates of anemia ${ }^{2,11}$.

Maternal nutrition has a low effect on the production and composition of human milk, since the lactating mother is able to mobilize nutrients from her own organism even in the presence of malnutrition. Under these conditions, the concentration of the human milk components is conserved, except for the lipid fraction ${ }^{2,60}$.

Lactation is believed to cause rapid weight loss in the lactating mother, especially during the first month post partum, and persists, to a lesser extent, until the time of weaning ${ }^{61}$. There are 
also reports showing a lower risk of osteoporosis in breastfeeding women ${ }^{62}$.

Breastfeeding has been suggested to exert a protective function against breast cancer. The longer the duration of breastfeeding, the lower the risk of developing this type of tumor during the premenopausal period ${ }^{63}$. A negative correlation between breastfeeding and ovarian cancer has also been reported $^{64}$. The contraceptive effect of lactation, with a consequent increase in the interval between gestations, is important to reduce maternal morbidity and mortality in developing countries $^{65,66}$.

The practicality of feeding maternal milk is unquestionable, since no mixing, heating or sterilizing is required and the milk is always available at the adequate temperature, in an unbreakable container and especially projected $^{7}$. Therefore, breastfeeding is the ideal method for feeding newborns and nursing infants and should be exclusively used until six months of age $\mathrm{e}^{67}$. After this age, complementation food should be offered, but breastfeeding can be beneficially maintained until two years or more ${ }^{67,68}$.

\section{BREASTFEEDING AND EARLY WEANING}

Despite the qualities of maternal breastfeeding, a decline in the worldwide rates of breastfeeding was observed at the end of the 19th century, at the time of the Industrial Revolution and was intensified after World War II. This decrease started in the urban centers of developed countries and has gradually spread to developing countries $^{69}$.

The reasons for this decline have been attributed to processes of urbanization and industrialization, including working mothers, occupation of women in modern society, the advent of milk products exclusive for nursing infants, valorization of the breast as a sex symbol, lack of enthusiasm on the part of health professionals, and lack of knowledge about the advantages of breastfeeding on the part of the mothers $^{70}$. As a result of urbanization, the extended family has been replaced by the nuclear family, with girls having fewer opportunities to learn informally the art of breastfeeding ${ }^{71}$.

In Brazil, this phenomenon was correlated with economic transformations that occurred at the beginning of the 20th century, accompanied by urban-industrial growth which favored the occurrence of the nuclear family and a consumer society, leading to the use of bottles and importation of industrialized milk ${ }^{11}$. National production of artificial milk, which was amplified at the beginning of the forties, and exaggerated advertising of maternal milk supplements have stimulated early weaning ${ }^{11,72}$.

Awareness of this problem and its consequences, especially infant mortality due to malnutrition and gastroenterocolitis $^{34}$, led to the creation of the National Program for the Encouragement of Breastfeeding (PNIAM) in 1981 by the Ministry of Health, which represented an ample educational program with the objective to rescue natural feeding ${ }^{72,73}$.

The decade of the eighties was characterized by the valorization of breastfeeding, with the development of a worldwide movement on behalf of the rescue of breastfeeding ${ }^{74-77}$. In 1989, the World Health Organization and UNICEF promoted a meeting in Florence, Italy, attended by representatives of various countries, including Brazil, who signed the "Innocenti Declaration"78 which determined actions to be implemented by health services to facilitate breastfeeding. On this occasion, the "Baby-Friendly Hospital Initiative" was created to stimulate maternity hospitals to promote, protect and support natural feeding, based on the rules of the "Ten Steps to Successful Breastfeeding""78.

This set of measures started with the preparation of health professionals who, from the prenatal period on, were provided with correct information about the qualities of natural feeding and guidance to solve problems of lactation $^{79,80}$. The latter aspect is as important as the former since most pregnant women, although recognizing the superiority of breastfeeding, lack knowledge about the art of breastfeeding ${ }^{81}$.

The implementation of the strategy "Baby-Friendly Hospital" has been related to a significant increase in the duration of breastfeeding of term newborns ${ }^{82}$; however, information regarding its impact on the feeding of premature infants is still insufficient.

\section{USE OF HUMAN MILK IN PREMATURE INFANTS}

The recommendation of breastfeeding for the premature newborn has been defended on the basis of the immunological properties of human milk, its role in gastrointestinal maturation, formation of the mother-child bond, and improvement in neurobehavioral performance, shown by breastfed children $^{83,84}$. Feeding of premature infants with human milk has been suggested to have short-, medium- and long-term benefits ${ }^{85}$. Premature infants show a better suction-deglutition coordination during breastfeeding. The transcutaneous partial oxygen pressure levels, oxygen saturation and body temperature have been shown to be higher than those observed during bottle feeding $^{86-89}$, confirming that breastfeeding is a more physiological process.

Human milk exerts a protective effect on premature infants against necrotizing enterocolitis. Lucas and Cole $\mathrm{e}^{90}$ observed a six to ten times higher incidence of this disorder in premature newborns who exclusively received 
artificial milk compared to those fed human milk. Likewise, the incidence of any infection, including sepsis and meningitis, has been found to be significantly lower among very low birthweight newborns fed human milk than among those receiving exclusively artificial milk ${ }^{91,92}$.

During the hospital stay of the mother and the premature infant, the mother produces antibodies against nosocomial microorganisms that occur at the neonatal unit, a fact important for the prevention of infection in the neonate during the hospital stay ${ }^{93}$. These data were confirmed by the observation of a significant reduction in the incidence of severe infections in patients submitted to the Kangaroo Mother Care, in which the newborn is maintained in a vertical position, in prone decubitus, against the mother, leading to early and growing contact between them ${ }^{94}$, compared to patients treated by the traditional method ${ }^{95,96}$.

Maternal milk has been found to protect premature infants with a family history of atopy against allergy, especially in terms of the incidence of eczema. After 18 months of age, children who received artificial milk showed a higher risk of developing this type of reaction than those receiving human milk from a milk bank ${ }^{97}$.

Omega 3 fatty acids are essential for a normal development of the retina, especially in very low birthweight newborns ${ }^{98}$. These fatty acids, together with antioxidant substances such as vitamin $\mathrm{E}, \beta$-carotene and taurine, might explain the protective effect of human milk on the development of premature retinopathy, since the incidence and severity of this disease are significantly lower in premature infants exclusively fed with maternal milk or who ingested at least $80 \%$ of their milk in the form of human milk ${ }^{99}$.

Lucas et al. ${ }^{100,101}$ observed advantages in terms of cognitive performance, assessed at 18 months and be- tween 7.5 and 8 years of age, in preterm children fed human milk. This study was carried out with scientific rigor, with adjustment for factors such as social class and educational level of the mother, days of mechanical ventilation, and gender. Since most premature newborns received milk by gavage, there is evidence that the best psychomotor development was due to the milk itself and not to the quality of mother care, supporting the statement that human milk is the optimal diet for the developing brain ${ }^{102}$.

Epidemiological evidence suggests that feeding human milk is related to a lower incidence of rehospitalization of premature infants, even after the introduction of food supplements. Therefore, even partial breastfeeding should be encouraged in this population ${ }^{8,85,93}$.

The biological benefits of maternal milk render it an excellent food for premature newborns, even when considering that eventual losses of nutrients due to collection, processing and storage and to the method used to offer human milk to patients of neonatal units $^{83,103-107}$ might be responsible for the lower growth rate observed for these newborns compared to those receiving artificial milk ${ }^{108}$. Although neonatal growth performance is better in preterm infants fed premature formulas, this is not true for measurements of weight, height, head circumference and cutaneous fold around nine months and eight years of age, which were found to be similar irrespective of whether the diet received was preferentially maternal milk or exclusively artificial milk ${ }^{109}$.

The diet of choice for premature newborns is the milk of their own mothers. In the case the child is unable to directly suck at the breast, it should receive manually expressed milk. When necessary, this milk should be supplemented with nutrients that are found in human milk itself (reformulated human milk) $)^{110}$. Another feeding strategy, which results in a better weight gain of premature newborns, is to offer hindmilk that contains up to three times more fat than foremilk ${ }^{111}$. The milk produced by mothers of premature newborns during the first four weeks post partum contains a higher concentration of nitrogen, proteins with immunological functions, total lipids, medium chain fatty acids, vitamins A, D and E, calcium, sodium, and energy than the milk of mothers of term infants. Therefore, milk obtained from the milk bank pool might be nutritionally inadequate for premature infants $^{12,112}$.

Industrialized additives derived from cow's milk are available and recommended by some sources in order to satisfy the nutritional needs of the child $^{16,113}$. A wide variety of human milk additives exists, most of them prepared on the basis of protein, carbohydrates, calcium, phosphorus, magnesium and sodium, which can also contain zinc, copper and vitamins ${ }^{114}$. The addition of these nutrients of bovine origin to human milk has guaranteed appropriate growth rates for very low birthweight newborns ${ }^{113,115}$, without affecting gastric emptying or food tolerance $^{116}$.

Neonatologists need not only to be convinced of the multiple advantages of breastfeeding and of the possibility to feed human milk to premature newborns, but should also integrate the management of lactation into the planning of therapeutic actions for these patients ${ }^{117}$. In view of the enormous advances in neonatology since the end of the sixties, especially the development of new support techniques for critically ill newborns, a population of premature very low birthweight newborns has arisen, which, until recently, did not survive and which, due to treir immaturity and clinical complications, is subject to childhood malnutrition and rehospitalization $^{118}$. Studies making breast- 
feeding viable for this risk population have unquestionable social importance since these children, due to their immunological impairment ${ }^{119}$, would particularly benefit from breastfeeding, especially in Brazil, a developing country with high infant mortality rates and endemic malnutrition in various regions ${ }^{120}$.

Although desirable, a low success rate of breastfeeding has been observed among mothers of premature neonates $^{121}$, since many hospital barriers to breastfeeding still exist ${ }^{122}$, especially in high risk neonatology services ${ }^{123}$, and weaning from the breast frequently occurs even before discharge of the premature newborn from the high risk nursery ${ }^{124}$.

During the stay at the neonatal unit, many mothers perceive that nursing their child is the only thing that they can effectively do to collaborate in the recovery of the premature newborn; however, only few mothers are able to initiate and maintain an adequate milk production without quali- fied help and family support ${ }^{125}$.

Breastfeeding premature infants represents a challenge. The premature newborn shows physiological and neurological immaturity, muscle hypotony and hyperreactivity to environmental stimuli, and remains alert for short periods of time only ${ }^{126}$. However, despite its inadequate suctiondeglutition-respiration control ${ }^{127}$, a premature newborn is able to feed at the breast as long as appropriate help is provided ${ }^{128}$.

The success of the work of promotion, protection and support for breastfeeding in premature infants depends on an interdisciplinary team consisting of neonatologists, nursing professionals, nutritionists, occupational therapists, physiotherapists, social assistants and phonoaudiologists, who should be prepared to integrate the clinical hospital management of lactation within the routine functioning of high risk nurseries. This team should be motivated and capable to provide consistent information about breastfeeding to the mother. This, in turn, requires training in health education and a true revolution in the habits of clinical management and, consequently, subsidies for the functioning of the program.

It is also compensatory to help mothers of premature infants, who frequently experience feelings of guilt and anger, by showing that breastfeeding, in addition to being important for the health and development of the newborn, is a practical and positive way for the mother to cope with the early birth of their child.

Even better would be to permit that hospitalized premature newborns be neither deprived of the presence of their mothers nor of breastfeeding. As Colette Clark said:

"The newborn has only three essential needs: the human warmth of the mother's arms, the certainty of the mother's presence, and the milk of her breasts. Breastfeeding satisfies all three."

\section{RESUMO}

NASCIMENTO MBR do e col. - Aleitamento materno: fazendo a diferença no desenvolvimento, saúde e nutrição dos recém-nascidos de termo e pré-termo. Rev. Hosp. Clín. Fac. Med. S. Paulo 58(1):49-60, 2003.

O aleitamento materno é o modo natural e seguro de alimentação para a criança pequena, proporcionando vantagens nutricionais, imunológicas, psi- cológicas e econômicas reconhecidas e inquestionáveis. Estas qualidades adquirem relevo especial em se tratando de recém-nascidos pré-termo, por sua maior vulnerabilidade. Apesar de altamente desejável, observa-se, de modo geral, baixa incidência de êxito na amamentação de prematuros, especialmente em unidade neonatais de risco. Há evidências de que uma postura hospitalar favorável, com apoio de uma equipe multiprofissional, torne possível o aleitamento nestas crianças. Neste artigo, os autores apresentam uma revisão atualizada sobre os componentes do leite humano e suas características únicas, bem como descrevem aspectos que tornam o leite materno particularmente adequado para a alimentação do recémnascido prematuro.

DESCRITORES: Alimentação infantil. Aleitamento materno. Leite humano. Recém-nascido. Prematuro. 


\section{REFERENCES}

1. AKRÊ J - Alimentação Infantil: bases fisiológicas. IBFAN/ Instituto de Saúde de São Paulo, 1994. (Trad. Anna Volochko).

2. VALDÉS V, SÁNCHES AP, LABBOK M - Manejo clínico da lactação: assistência à nutriz e ao lactente. Rio de Janeiro, Revinter, 1996. (Trad. Marcus Renato de Carvalho).

3. PICCIANO MF - Human milk: nutritional aspects of a dynamic food. Biol Neonate. 1998; 74:84-93.

4. KUNZ C, RODRIGUEZ-PALMERO M, KOLETZKO B et al. Nutritional and biochemical properties of human milk, part I: general aspects, proteins and carbohydrates. Clin Perinatol 1999; 26:307-333.

5. RODRIGUEZ-PALMERO M, KOLETZKO B, KUNZ C et al. Nutritional and biochemical properties of human milk, part II: lipids, micronutrients and bioactive factors. Clin Perinatol 1999; 26:335-359.

6. WORLD health organization (WHO) - Collaborative Study Team on the role of Breastfeeding on the prevention of infant mortality. Effect of breastfeeding on infant and child mortality due to infectious disease in less developed countries: a pooled ananlysis. Lancet 2000; 355:451-455.

7. MULLER M - O matador de bebês. Recife, Companhia Editora de Pernambuco, 1995.

8. RIORDAN J - The biologic specificity of breastmilk. In: RIORDAN J, AUERBACH KG - Breastfeeding and human lactation. 2.ed. Boston, Jones and Bartlett Publishers, 1998. p. 121-161.

9. RUOCCO RMSA - Colostro humano: contribuição ao estudo da sua composição leucocitária. São Paulo, 1992. Tese (Doutorado) - Faculdade de Medicina, Universidade de São Paulo.

10. LAWRENCE RA - Breastfeeding: a guide for the medical profession. $4^{\text {th }}$ ed. St. Louis, Mosby, 1994.

11. ALMEIDA JAG - Amamentação: um híbrido natureza-cultura. Rio de Janeiro, Editora Fiocruz, 1999.

12. GROSS SJ, DAVID RJ, BAUMANN L et al. - Nutritional composition of milk produced by mothers delivering preterm. J Pediatr 1980; 96:641-644.

13. CALIL VMLT - Composição nutricional do colostro de mães de recém-nascidos adequados e pequenos para a idade gestacional. São Paulo, 1990. Dissertação (Mestrado) Faculdade de Medicina, Universidade de São Paulo.

14. LAWRENCE PB - Breast milk: best source of nutrition for term and preterm infants. Ped Clin North Am 1994; 41:925-941.

15. SCAGLIA F, LONGO N - Primary and secondary alterations of neonatal carnitine metabolism. Semin Perinatol 1999; 23:152-161.

16. CANADIAN paediatric society (CPS) - Nutrition Comittee. Nutrition needs and feeding of premature infants. Can Med Assoc J 1995;152:1765-1785.
17. HAMOSH M, SALEM N Jr. - Long-chain polyunsaturated fatty acids. Biol Neonate 1998; 74:106-120.

18. VAN BEEK RHT, CARNIELLI VP, SAUER PJJ - Nutrition in the neonate. Curr Opin Pediatr 1995; 7:146-151.

19. UAUY R, HOFFMAN DR - Essential fat requirements of preterm infants. Am J Clin Nutr 2000; 71 Suppl:245-250.

20. SCHANLER RJ, HURST NM, LAU C - The use of human milk and breastfeeding in premature infants. Clin Perinatol 1999; 26:379-398

21. FALLOT ME, BOYD JL, OSKI F - Breast-feeding reduces incidence of hospital admissions for infection in infants. Pediatrics 1980; 65:1121-1124.

22. VICTORA CG, VAUGHAN JP, LOMBARDI $\mathrm{C}$ et al. - Evidence for protection by breast-feeding against infant deaths from infectious diseases in Brazil. Lancet 1987; 2:319-322.

23. WRIGHT A, HOLBERG CJ, MARTINEZ FD et al. - Breastfeeding and lower respiratory tract ilness in the first year of life. BMJ 1989; 299:946-949

24. HOWIE PW, FORSYTH JS, OGSTON AS et al. - Protective effect of breastfeeding against infection. BMJ 1990; 300:1116.

25. XANTHOU M - Immune protection of human milk. Biol Neonate 1998; 74: 121-133

26. GRUMACH AS, CARMONA RC, LAZAROTTI D et al. Immunological factors in milk from brazilian mothers delivering small-for-date term neonates. Acta Paediatr 1993; 82: $284-290$

27. HAMOSH M - Protective function of proteins and lipids in human milk. Biol Neonate 1998; 74:163-176.

28. PETERSON JÁ, PATTON S, HAMOSH M - Glycoproteins of the human milk fat globule in the protection of the breastfed infant against infections. Biol Neonate 1998; 74:143162 .

29. GAROFALO RP, GOLDMAN AP - Cytokines, chemokines, and colony-stimulating factors in human milk: the 1997 update. Biol Neonate 1998; 74:134-142.

30. GRAZIOSO CF, WERNER AL, ALLING DW et al. Antiinflamatory effects of human milk on chemically induced colitis in rats. Pediatr Res 1997; 42:639-643.

31. GAROFALO RP, GOLDMAN AP - Expression of functional immunomodulatory and anti-inflammatory factors in human milk. Clin Perinatol 1999; 26:361-377.

32. SIROTA L, STRAUSSBERG R, NOTTI I et al. - Effect of human colostrum on interleukin-2 production and natural killer cell activity. Arch Dis Child 1995; 73: 99-102.

33. CÉSAR JÁ, VICTORA CG, BARROS FC et al. - Impact of breast feeding on admission for pneumonia during postneonatal period in Brazil: nested case-control study. BMJ 1999; 318:1316-1320. 
34. SIGULEM DM, TUDISCO ES - Aleitamento natural em diferentes classes de renda no município de São Paulo. Arch Latinoam Nutr 1980; 30:400-416.

35. COUSENS S, NACRO B, CURTIS V et al. - Prolonged breastfeeding: no association with increased risk of clinical malnutritionin young children in Burkina Faso. WHO Bulletin 1993; 71:713-722.

36. ISLAM MA, RAHMAN MM, MAHALANABIS D - Maternal and socioeconomic factors and the risk of severe malnutrition in a child: a case-control study. Eur J Clin Nutr 1994; 48: 416-424.

37. DUNCAN B, EY J, HOLBERG CJ et al. - Exclusive breastfeeding for at least 4 months protects against otitis media. Pediatrics 1993; 91:867-871.

38. PISACANE A, GRAZIANO L, MAZZARELLA G et al. - Breast feeding and urinary tract infection. J Pediatr 1992; 120:8790 .

39. SILFVERDAL AS \& OLCÉN P - Protective effect of breastfeeding: an ecologic study of Haemophilus influenzae meningitis and breastfeeding in a Swedish population. Int $\mathbf{J}$ Epidemiol 1999; 28:152-156.

40. MERRET TC, BURR ML, BUTLAND BK Infant feeding and allergy: twelve-month prospective study of 500 babies born in allergic families. Ann Allergy 1988; 61:13-20.

41. HARRIS MC, KOLSKI GB, CAMPBELL DE - Ontogeny of the antibody response to cow milk proteins. Ann Allergy 1989; 63:439-442.

42. SAARINEN UM, KAJOSAARI M - Breast-feeding as prophylaxis against atopic disease: prospective follow-up study until 17 years old. Lancet 1995; 346: 1065-1069.

43. MAYER EJ, HAMMAN RF, GAY EC et al. - Reduced risk of IDDM among breast-fed children. Diabetes 1988; 37:16251632 .

44. DAVIS MK, SAVITZ DA, GRAUBARD BI - Infant feeding and childhood cancer. Lancet 1988; 2:365-368.

45. KOLETZKO S, SHERMAN P, COREY M et al. - Role of infant feeding practices in development of Crohn's disease in childhood. BMJ 1989; 298:1617-1618.

46. FREUDENHEIN JL, MARSHAL JR, GRAHAN $\mathrm{S}$ et al. Exposure to breastmilk in infancy and the risk of breast cancer. Epidemiology 1994; 5:324-331.

47. HAHN-ZORIC M, FULCONIS F, MINOLI I et al. - Antibody response to parenteral and oral vaccines are impaired by conventional and low protein formulas as compared to breastfeeding. Acta Paediatr Scand 1990; 79:1137-1142.

48. PALMER B - The influence of breastfeeding on the development of the oral cavity: a commentary. J Hum Lact 1998; 114:9398 .

49. LOESCHE WJ - Nutrition and dental decay in infants. Am J Clin Nutr 1985; 41: 423-435.

50. MCVEA KLSP, TURNER PD, PEPPLER DK - The role of breastfeeding in sudden infant death syndrome. J Hum Lact 2000; 16: 13-20.
51. VON KRIES R, KOLETZKO B, SAUERWALD T et al. Breastfeeding and obesity: cross sectional study. BMJ 1999; 139:147-150.

52. KLAUS MH, KLAUS PH - The amazing newborn. Massachussetts, Addison-Wesley Pub, 1992.

53. VINHA VHP - Amamentação materna: incentivo e cuidados. São Paulo, Sarvier, 1983.

54. KLAUS MH, KENNEL JH - The doula: an essential ingredient of childbirth rediscovered. Acta Paediatr 1997; 86:1034 1036.

55. LEHTONEN J, KÖNÖNEN M, PURHONEN M et al. - The effect of nursing on the brain activity of the newborn. J Pediat 1998; 132:646-651.

56. ANDERSON JW, JOHNSTONE BM, REMLEY DT Breastfeeding and cognitive development: a meta-analysis. Am J Clin Nutr 1999; 70:525-535.

57. VILLALPANDO S, HAMOSH M - Early and late effects of breast-feeding: does breast-feeding really matter? Biol Neonate 1998; 74:177-191

58. BALL TM, WRIGHT AL - Health care costs of formula-feeding in the first year of life. Pediatrics 1999; 103:870-676.

59. SCHMIED V, BARCLAY L - Connection and pleasure, disruption and distress: women's experience of breastfeeding. J Hum Lact $1999 ; 15: 325-334$.

60. RIORDAN J, AUERBACH KG. - Maternal health. In: RIORDAN J, AUERBACH KG - Breastfeeding and human lactation. Boston, Jones and Bartlett Pub, 1993. p. 349-377.

61. ABUSABHA R, GREENE G - Body weight, body composition, and energy intake changes in breastfeeding mothers. J Hum Lact 1998; 114:119-124,.

62. KRITZ-SILVERSTEIN D, BARRET-CONNOR E, HOLLENBACH KA -Pregnancy and lactation as determinants of bone mineral density in postmenopausal women. Am J Epidemiol 1992; 136:1052-1059.

63. BYERS T, GRAHAM S, RZEPKA T et al. - Lactation and breast cancer: evidence for a negative association in premenopausal women. Am J Epidemiol 1985; 121:664-674.

64. SCHNEIDER AP - Risk factor for ovarian cancer [Letter]. N Engl J Med 1987; 317:508-509.

65. SAADEH R, BENBOUZID D - Lactancia materna e espaciamento de los nacimientos: importancia de la obtención de información para las políticas de salud pública. Bol of Sanit Panam 1991; 111:122-130.

66. KENNEDY KI, KOTELCHUCK M - Policy considerations for the introduction and promotion of the Lactacional Amenorrhea Method: advantages and disadvantages of LAM. J Hum Lact 1998; 14:191-203,.

67. WORLD Health Organization (WHO). - The optimal duration of exclusive breastfeeding. Note for the press n. ${ }^{\circ} 7$, April 2 , 2001. Available at: http://www.who.int/inf-pr-2001/en/ note2001-07.html. 
68. WORLD Health Organization (WHO). - Indicators for assessing breast-feeding practices. Geneva, 1991.

69. COATES MM - Tides in breastfeeding practices. In: RIORDAN J, AUERBACH KG - Breastfeeding and human lactation. Boston, Jones and Bartlett Pub, 1993. p. 3-26.

70. JELLIFFE DB - Evolución de la alimentación infantil. In: OMS - La nutrición infantil en las zonas tropicales e subtropicales. Ginebra, Organización Mundial de la Salud, 1970; 29:13-32. Série de monografias.

71. JELLIFFE DB \& JELLIFFE EFP - Human milk in the modern world. $2^{\text {nd }}$ ed. New York, Oxford University Press, 1979.

72. MINISTÉRIO DA SAÚDE (MS). - Instituto Nacional de Alimentação e Nutrição. Programa nacional de aleitamento materno. Brasília, 1991

73. MATTAI J. - The brazilian national breast-feeding program. Assign Child 1983; 6:225-247.

74. FEINSTEIN JM, BERKELHAMER JE, GRUSKA ME et al. Factors related to early termination of breastfeeding in an urban population. Pediatrics 1986; 78:210-215.

75. BARROS FC, VICTORA CG, VAUGHAN JP - Breastfeeding and socioeconomic status in southern Brazil. Acta Paediatr Scand 1986; 75:558-562.

76. ISSLER H, LEONE C, QUINTAL VS. - Duração do aleitamento materno em uma área urbana de São Paulo, Brasil. Bol Of Sanit Panam 1989; 106:513-522.

77. WEILE B, RUBIN DH, KRASILNIKOFF PA et al. - Infant feeding patterns during the first year of life in Denmark: factors associated with the discontinuation of breastfeeding. J Clin Epidemiol 1990; 43:1305-1311.

78. WORLD Health Organization (WHO)/UNICEF - Protecting, promoting and supporting breastfeeding: the special role of maternity services. A joint WHO/UNICEF statement. Geneva, 1989.

79. LAMOUNIER JA - Promoção e incentivo ao aleitamento materno: Iniciativa Hospital Amigo da Criança. J pediatr (Rio J) 1996; 72:363-368.

80. NEIFERT MR - The optimization of breast-feeding in the perinatal period. Clin Perinatol 1998; 25:303-326.

81. ISSLER H, SÁ MBSR, SENNA DM. - Knowledge of newborn healthcare among pregnant women: basis for promotional and educational programs on breastfeeding. São Paulo Med J/ Rev Paul Med 2001; 119:7-9.

82. WRIGHT A, RICE S, WELLS S - Changing hospital practices to increase the duration of breastfeeding. Pediatrics 1996; 97:669-675.

83. SCHANLER RJ, HURST NM - Human milk for the hospitalized preterm infant. Semin Perinatol 1994;18:476-484.

84. SCHANLER RJ - Suitability of human milk for the low birthweight infant. Clin Perinatol 1995; 22:207-222.

85. MEIER P, BROWN L - State of the Science: Breastfeeding for mothers and low birth weight infants. Nurs Clin North Am 1996; 31:351-365.
86. MEIER P, ANDERSON GC - Responses of small preterm infants to bottle and breastfeeding. MCN Am Matern Child Nurs 1987; 12:97-105.

87. MEIER P - Bottle and breastfeeding : effects on transcutaneous oxygen pressure and temperature in preterm infants. Nurs Res 1988; 37:36-41.

88. BIER JB, FERGUSON A, ANDERSON L et al. - Breast-feeding of very low birth weight infants. J Pediatr 1993; 123:773-778.

89. CHEN C, WANG T, CHANG H et al. - The effect of breast and bottle-feeding on oxygen saturation and body temperature in preterm infants. J Hum Lact 2000; 16:21-27.

90. LUCAS A, COLE TJ - Breastmilk and neonatal necrotising enterocolitis. Lancet 1990; 336:1519-1523.

91. EL-MOHANDES AAE, PICARD M, SIMMENS SJ - Human milk utilization in the ICN decreases the incidence of bacterial sepsis [abstract]. Pediatr Res 1995; 37:306A.

92. HYLANDER MA, STROBINO DM, DHANIREDDY R - Human milk feedings and infection among very low birth weight infants [abstract]. Pediatrics 1998; 102:630.

93. GOLDMAN AS, CHHEDA S, KEENEY SE et al. - Immunologic protection of the premature newborn by human milk. Semin Perinatol 1994; 18:495-501.

94. MINISTÉRIO da Saúde (MS) - Secretaria de políticas de saúde. Área técnica da saúde da criança. Normas de atenção humanizada ao recém-nascido de baixo peso: Método Canguru. Brasília, 1999.

95. SLOAN NL, CAMACHO LWL, ROJAS EP et al. - Kangaroo mother method: randomised controlled trial of an alternative method of care for stabilised low-birthweight infants. Lancet 1994; 344:782-785.

96. CHARPAK N, RUIZ-PELÁEZ JG, CALUME ZF et al. Kangaroo mother versus traditional care for newborn infants $<2000$ grams: a randomized, controlled trial. Pediatrics 1997; 100:682-688.

97. LUCAS A, BROOKE OG, MORLEY R et al. - Early diet of preterm infants and development of allergic or atopic disease: randomised prospective study. BMJ 1990; 300:837-840.

98. UAUY RD, BIRCH DG, BIRCH EE et al. - Effect of dietary Omega-3 fatty acids on retinal function of very low birth weight neonates. Pediatr Res 1990; 28:485-492.

99. HYLANDER MA, STROBINO DM, DHANIREDDY R - Human milk feedings and retinopathy of prematurity among very low birth weight infants [abstract]. Pediatr Res 1996; 37:214A.

100. LUCAS A, MORLEY R, COLE TJ et al. - Early diet in preterm babies and developmental status at 18 months. Lancet 1990; 335: $1477-1481$.

101. LUCAS A, MORLEY R, COLE TJ et al. - Breastmilk and subsequent intelligence quotient in children born preterm. Lancet 1992; 339:261-264.

102. UAUY R, PEIRANO P. - Breat is best: human milk is the optimal food for brain development. Am J Clin Nutr 1999; 70:433434. 
103. WILLIAMSON S, FINUCANE E, ELLIS H et al. - Effect of heat treatment of human milk on absorption of nitrogen, fat, sodium, calcium and phosphorus by preterm infants. Arch Dis Child 1978; 53:555-563.

104. BATES CJ, LIU DS, FULLER NJ et al. - Susceptibility of riboflavin and vitamin A in breast milk to photodegradation and its implications for the use of banked breast milk in infant feeding. Acta Paediatr Scand 1985; 74:40-44.

105. STEIN H, COHEN D, HERMAN AAB et al. - Pooled pasteurized breast milk and untreated own mother's milk in the feeding of very low birthweight babies: a randomized controlled trial. J Pediatr Gastroenterol Nutr 1986; 5:242-247.

106. PARDOU A, SERRUYS E, MASCART-LEMONE F et al. - Human milk banking: influence of storage processes and of bacterial contamination on some milk constituents. Biol Neonate 1994; 65:302-309.

107. JOCSON MA, MASON EO, SCHANLER R.J - The effects of nutrient fortification and varying storage conditions on host defense properties of human milk. Pediatrics 1997; 100:240243.

108. NICHOLL RM GAMSU HR - Changes in growth and metabolism in very low birthweight infants fed with fortified breast milk. Acta Paediatr 1999; 88:1056-1061.

109. MORLEY R, LUCAS A - Randomized diet in the neonatal period and growth performance until 7,5-8y of age in preterm children. Am J Clin Nutr 2000; 71:822-828.

110. VINAGRE RD - Análise crítica do uso do leite humano procedente de banco de leite na alimentação do recém-nascido prematuro. São Paulo, 1999. Dissertação (Mestrado) - Faculdade de Medicina, Universidade de São Paulo.

111. VALENTINE CJ, HURST NM, SCHANLER R.J - Hindmilk improves weight gain in low-birth-weight infants fed human milk. J Ped Gastroenterol Nutr 1994; 18:474-477.

112. ATKINSON SA - Human milk feeding of the micropremie. Clin Perinatol 2000; 27:235-247.

113. GUERRINI P - Human milk fortifiers. Acta Paediatr 1994; 402:37-39. Supplement.

114. SCHANLER RJ - Fortified human milk: the nature's way to feed premature infants. J Hum Lact 1998; 14:5-11.

115. SCHANLER RJ, SHULMAN RJ, LAU C - Growth of premature infants fed fortified human milk. Pediatr Res 1997; 41:240A.
116. MCCLURE RJ, NEWELL SJ - Effect of fortifying brest milk on gastric emptying. Arch Dis Child 1996; 74:60-62.

117. AMERICAN academy of pediatrics (AAP) - Work group on breastfeeding. Breastfeeding and the use of human milk. Pediatrics 1997; 100:1035-1039.

118. BERNFIELD M - Foreword. In: CLOHERTY J, STARK AR ed. - Manual of Neonatal Care. Boston, Little Brown, 1991.

119. FALCONER AE, CARR, EDWARDS SW - Impaired neutrophil phagocytosis in preterm neonates: lack of correlation with expression of immunoglobulin or complement receptors. Biol. Neonate 1995; 68:264-269 .

120. MINISTÉRIO DA SAÚDE (MS). Secretaria de assistência à saúde. Coordenação materno-infantil. Manual de assistência ao recém-nascido. Brasília, 1994.

121. WOHLBERG LK, GEARY BF. - Team approach to breastfeeding the ELBW infant: a case report. J Hum Lact 1994; 10:181183.

122. POWERS NG, NAYLOR AJ, WESTER RA - Hospital policies: crucial to breastfeeding success. Semin Perinatol 1994; 18:517-524.

123. PANTAZI M, JAEGER MC, LAWSON M - Staff support for mothers to provide breast milk in pediatric hospitals and neonatal units. J Hum Lact; 14:291-296.

124. RICHARDS MT, LANG MD, MCINTOSH C et al. - Breastfeeding the VLBW infant: sucessful outcome and maternal expectation. Pediatr Res 1986; 20:383A.

125. MCCOY R, KADOWAKI C, WILKS $\mathrm{S}$ et al. - Nursing management of breastfeedinf for preterm infants. J Perinat Neonatal Nurs 1988; 2:42-55.

126. NYQVIST KH, EWALD U, SJÖDÉN P - Supporting a preterm infant's behaviour during breastfeeding: a case report. J Hum Lact 1996; 12:221-228.

127. JAIN L, SIVIERI E, ABBASI S et al. - Energetics and mechanics of nutritive sucking in the preterm and term neonate. $\mathbf{J}$ Pediatr 1987; 111:894-898.

128. DROSTEN F - Case management of a premature infant transitioning to the breast. J Hum Lact 2001; 17:47-50. 